\title{
Effects of Short-term Acute Heat Stress on Physiological Responses and Heat Shock Proteins of Hanwoo Steer (Korean Cattle)
}

\author{
Youl-Chang Baek, ${ }^{1, \#}$, Minseok Kim ${ }^{2, \#}$, Jin-Young Jeong ${ }^{1}$, Young-Kyoon $\mathrm{Oh}^{1}$, Sung-Dae Lee ${ }^{1}$, \\ Yoo-Kyung Lee ${ }^{1}$, Sang-Yun $\mathrm{Ji}^{1}$ and Hyuck Choi ${ }^{3, *}$ \\ ${ }^{1}$ Animal Nutrition \& Physiology Team, National Institute of Animal Science, Rural Development Administration, Wanju \\ 55365, Korea \\ ${ }^{2}$ Department of Animal Science, College of Agriculture and Life Sciences, Chonnam National University, Gwangju \\ 61186, Korea \\ ${ }^{3}$ Department of Pet Science, Seojeong College, Yangju 11429, Korea
}

Received August 30, 2019

Revised September 18, 2019

Accepted September 23, 2019

*Correspondence

Hyuck Choi

E-mail: hchoi@seojeong.ac.kr

ORCID

https://orcid.org/0000-0002-7047-6472

"Both authors contributed equally to this paper.
ABSTRACT This study was performed to evaluate the effect of heat stress on the status of physiological responses, blood parameter, serum T3 and cortisol, and heat shock proteins (HSP 27, 70, and 90) of Hanwoo cattle. Six Hanwoo steers (242.8 \pm 7.2 $\mathrm{kg}$ of BW) were housed in the climate-controlled respiration chambers. The experiment consisted of 7 days (control; 0 day) at thermoneutral (air temperature (Ta) of $15^{\circ} \mathrm{C}$ and relative humidity $(\mathrm{RH})$ of $60 \%$; temperature-humidity index $(\mathrm{THI})=64)$, and by 3 and 6 days (treatment groups) at heat stress ( $\mathrm{Ta}$ of $35^{\circ} \mathrm{C}$ and $\mathrm{RH}$ of $60 \%$; $\mathrm{THI}=87$ ). Body temperature of each parts (frank, rump, perineum and foot) and rectal temperature elevated in heat stress groups ( 3 days and 6 days) than the control group ( 0 day). Respiration rates increased in 3 days and 6 days $(88.5 \pm 0.96 \mathrm{bpm}$ and $86.3 \pm 0.63 \mathrm{bpm}$, respectively) from 0 days (39.5 $\pm 0.65 \mathrm{bpm})$. Feed intake significantly decreased in heat stress groups ( 3 days and 6 days, $3.7 \pm 0.14 \mathrm{~kg}$ and $4.0 \pm 0.15 \mathrm{~kg}$, respectively) than the control group ( 0 day, $5.0 \pm 0.00 \mathrm{~kg}$ ). In addition, final BW significantly decreased in heat stress groups ( 3 days and 6 days, $211.8 \pm 4.75 \mathrm{~kg}$ and $215.5 \pm$ $3.50 \mathrm{~kg}$, respectively) than the control group (0 day, $240.0 \pm 25.00 \mathrm{~kg}$ ). However, heat stress has no significant effect on blood parameter, serum T3 and cortisol. Nevertheless, heat stress increased HSPs mRNA expression in liver tissue, and serum concentration of HSPs. Despite Hanwoo cattle may have high adaptive ability to heat stress, our results suggested that heat stress directly effect on body temperature and respiration rate as well as serum and tissue HSPs. Therefore, we are recommended that HSPs could be the most appropriate indicators of Hanwoo cattle response to heat stress.

Keywords: blood parameter, body temperature, heat shock protein, heat stress, respiration rate 


\section{INTRODUCTION}

The steady increase concentration of greenhouse gases (carbon dioxide, methane, nitrous oxide etc.) in the earth atmosphere due to electricity generation, fossil fuel consumption, transportation, changes of land use (e.g., deforestation), and even agriculture has raised the radiative heat of the troposphere and earth surface (Mitchell, 1989). This heat leads to extreme changes in climate and weather such as drought, intense rain and flood, as well as turning into severe heat waves regions and desertification in many areas of the world (Stringer et al., 2009). In addition, this heating is likely to be more enhanced by changes in water vapor, sea ice, and cloud (Mitchell, 1989). Consequently, the world average temperature has increased approximately by $0.6^{\circ} \mathrm{C}$ in over the past 100 years, and is predicted to rise anywhere between 1.4 to $5.8^{\circ} \mathrm{C}$ by the end of the century (Houghton et al., 2001).

Boo et al. (2004) have reported that daily temperature over South Korea are expected to increase by approximately $5.5^{\circ} \mathrm{C}$ between 1971 to 2000 and 2071 to 2100 . Moreover, reports showed that recently the severity of tropical nights significantly increased in South Korea (Park and Suh, 2011). These results implicate the possibility of heat stress exposure of livestock in South Korea due to global warming.

The predicted climate change will intensify exposure of animals to heat stress, which will have a major impact on the global livestock industries (St-Pierre et al., 2003). Heat stress in cattle has been reported to indirectly and directly affect feed intake, growth, reproduction, physiological, behavioral, metabolic disorders, health and others (Collier et al., 1982; West, 2003). Moreover, mild to severe heat stress have been estimated to increase the maintenance requirements of cattle by 7 to $25 \%$ (NRC, 2001).

The physiological response of Holstein calves to environmental stress during the winter and summer season showed influence on several serum biochemical parameters (Rasooli et al., 2004). Furthermore, heat stress have also been reported to cause alterations in endocrine status, thyroid status, and adrenal cortical hormone (e.g., cortisol) (Kahl et al., 2015). Particular thyroid hormones (e.g., triiodothyronine; T3 and thyroxine; T4) associated with metabolic homeostasis and regulation of thermogenesis are important considerations in the adaptation to heat stress (Melesse et al., 2011). However, these changes are related to the ability of different cattle breed to adapt to heat stress condition (Pereira et al., 2008). Therefore, it is recommended to further investigate physiological responses, blood parameter, levels of serum T3 and cortisol of Hanwoo cattle under heat stress as caused by global warming.

Heat stress regulates a variety of protein chaperone genes such as heat shock proteins (HSPs). HSPs are highly conserved family of molecular chaperones and are named according to their molecular weight expressed in kilodaltons (e.g., HSP27, HSP60, HSP70, HSP90, and HSP110) (Moseley, 1998). Previously, reports showed that heat stress response induced activation of the heat shock transcription factor (HSF), increased HSPs concentration in serum and HSPs gene expression in tissue (Min et al., 2015). Thus, HSPs are key factors in the cellular response and tissue homeostasis of heat stress on cattle.

Heat stress will become more of a concern in the future of Hanwoo cattle industry. However, the effect of heat stress on Hanwoo cattle has not clearly investigated. Therefore, the objective of the present study was to determine the influence of short-term acute heat stress on physiological response, blood parameters, level of serum T3 and cortisol, and HSPs of Hanwoo steer.

\section{MATERIALS AND METHODS}

\section{Climate-controlled respiration chamber}

This experiment was conducted in the climate-controlled respiration chamber at the National Institute of Animal Science. The climate-control respiration system consisted six chambers equipped with stanchion-stall barn. The entire chamber dimension is $230 \times 390 \times 260$ $\mathrm{cm}$ containing an individual stanchion-stall $(127 \times 250$ $\times 200 \mathrm{~cm})$ that equipped with rubber mat, feed bunk and automatic water bowl (cows had free access to drinking water). The chambers were designed to keep ambient temperature and relative humidity $(\mathrm{RH})$ in a rage from $20^{\circ} \mathrm{C}$ to $80^{\circ} \mathrm{C}$ and $0 \%$ to $100 \%$, respectively. In addition, this system allows the continuous monitoring of $\mathrm{O}_{2}, \mathrm{CO}_{2}$, and $\mathrm{CH}_{4}$ concentrations in chamber air. Each chamber was equipped with closed circuit television (CCTV), to record and observe the behavior of animals.

\section{Animals and experimental design}

This study was reviewed and approved by the Animal 
Ethics Committee of the National Institute of Animal Science, Korea. Six Hanwoo steers (210 kg to $259 \mathrm{~kg}$ of body weight, $242.8 \pm 7.2 \mathrm{~kg}$ of initial average body weigh) were randomly assigned to individual stanchion-stalls in each chamber. Individual feeding was done twice a day $(0900$ and $1700 \mathrm{~h}$ ) in equal parts of the daily diet, with water ad libitum and free-choice minerals. The diet consisted 2.0 $\mathrm{kg}$ rice straw with $3.0 \mathrm{~kg}$ concentrate mixture and a ratio of $4: 6$ on a DM base (Table 1). The basal diet was formulated to meet NRC requirements (NRC, 2001). Feed refusals were collected and weighed after the morning feeding of individual animals.

The experimental period consisted a total of 20 days. Acclimation period to stanchion-stall and chamber environment ranged from day 1 to 7 . Day 14 to 20 was for collection period. After 7 days of chamber adjustment, all steers were exposed to constant thermoneutral environment conditions [air temperature (Ta) of $15^{\circ} \mathrm{C}$ and $\mathrm{RH}$ of $60 \%$; THI $=64 ; 12$-h light and dark cycles] for $24 \mathrm{~h}$, for the first 7 days (day 7 to 14 ). Two steers were randomly collected on day 14 (control, 0 day). The next 6 days (day 14 to 20), four steers were exposed to constant heat environment conditions [ $\mathrm{Ta}$ of $35^{\circ} \mathrm{C}$ and $\mathrm{RH}$ of $60 \%$; $\mathrm{THI}=87$; 12-h light and dark cycles] for $24 \mathrm{~h}$. Two steers were randomly collected on day 17 (3 days), and finally two steers were collected on day 20 (6 days). Animals were weighed at the end of acclimation period and at the end of each collection period. All animals were euthanized through administration of $15 \mathrm{~mL}$ of $\mathrm{T} 61^{\circledR}$ euthanasia solution (Intervet International BV, Boxmeer, Netherlands) intravenous injection on days 14,17 , and 20 of collection period.

Table 1. Ingredient composition of concentrate mixture

\begin{tabular}{lc}
\hline \multicolumn{1}{c}{ Item } & \% of DM \\
\hline Ground corn & 47.9 \\
Wheat bran & 41.0 \\
Soybean meal & 5.0 \\
Rapeseed meal & 2.0 \\
Molasses & 2.0 \\
Dicalcium phosphate & 1.5 \\
Salt & 0.4 \\
Vitamin-mineral premix & 1.5 \\
Total & 0.2
\end{tabular}

Vitamin-mineral premix components: Vitamin A, 2,650,000 IU; Vitamin $D_{3}$, 530,000 IU; Vitamin E, 1,050 IU; Niacin, 10,000 mg; Mn, 4,400 mg; Fe, 13,200 mg; I, 440 mg; Co, 440 mg.

\section{Physiological parameters}

Body temperature, rectal temperature and respiration rate were obtained twice a day on collection period (at 0830 and $1630 \mathrm{~h}$ before the feeding). Body temperatures were measured on the flank, rump, perineum and foot of each steer using a portable infrared temperature gun (SK-8700II; Sato Keiryoki MFG, Tokyo, Japan; accuracy $\pm 1.0^{\circ} \mathrm{C}$ ). Rectal temperatures were also measured using a digital thermometer (MT200; Microlife, NeiHu Taipei, Taiwan; accuracy $\pm 0.1^{\circ} \mathrm{C}$ ). Respiration rates were determined by counting the number of flank movements for 60 $\mathrm{s}$ and reported as breath per min (bpm).

\section{Blood sampling and serum analysis}

Blood samples $(20 \mathrm{~mL})$ were collected immediately from each steer via jugular venipuncture with a non-heparinized tube before it was euthanized at the end of each collection period (on the days 14, 17, and 20). All blood samples were immediately placed on ice, transported to the laboratory within 30 minutes, and then serum was separated by centrifugation at 3,000 rpm for $20 \mathrm{~min}$ at $4^{\circ} \mathrm{C}$. All serum samples were harvested taken aliquots in $1 \mathrm{ml}$ amount to avoid repeated freeze-thaw cycles, and stored at $-80^{\circ} \mathrm{C}$ until analysis.

Serum T3, cortisol, HSP27, HSP70 and HSP90 levels were analyzed using commercially available enzymelinked immunosorbent assay (ELISA) kit. Concentration of serum T3 and cortisol were determined using Bovine ELISA kit (CSBE13049B and CSBE13064B, Cusabio Biotech, Wuhan, China). HSP27, HSP70 and HSP90 were measured using Bovine ELISA kit (MBS011935, MBS2882245 and MBS094979, MyBioSource, San Diego, CA, USA) in accordance to the manufacturer's instructions.

Serum glucose, blood urea nitrogen (BUN), creatinine, cholesterol, albumin and alanine aminotransferase (ALT) levels were measured using an IDEXX Catalyst Dx Chemistry Analyzer (IDEXX Laboratories, Maine, USA).

\section{Liver sampling and real-time PCR}

Liver tissue samples were immediately collected within 30 minutes after the euthanization of the animal. One sample of liver tissue from the caudate lobe was obtained from each animal. The liver tissue was cut into small pieces and immediately snap-frozen in liquid nitrogen, and placed in a sterile sample container, and then stored at $-80^{\circ} \mathrm{C}$ until RNA extraction. 
Total RNA were isolated from the liver tissue using TRIzol reagent (Invitrogen, Carlsbad, CA, USA) in accordance to the manufacturer's instructions. Total RNA concentrations were measured using a NanoDrop spectrophotometer (ND-1000; Thermo Fischer Scientific, Wilmington, DE, USA), and the integrity of the ribosomal RNA were assessed with 1\% agarose gel (Sigma Aldrich, St. Louis, MO, USA). DNA were synthesized from the extracted total RNA using Maxime RT PreMix Kit (iNtRon, Sungnam, Korea).

Expression of HSP27, HSP70 and HSP90 were quantitatively determined using Real-time polymerase chain reaction (PCR). Real-time PCR was performed on the ABI 7500 Fast Real-time PCR system (Applied Biosystems, Foster City, CA, USA) using Power SYBR Green PCR Master Mix (Applied Biosystems) according to the manufacturer's protocol. Cycling conditions were $95^{\circ} \mathrm{C}$ for $10 \mathrm{~min}$, followed by 40 cycles of $95^{\circ} \mathrm{C}$ for $30 \mathrm{~s}, 60^{\circ} \mathrm{C}$ for $30 \mathrm{~s}$, and $72^{\circ} \mathrm{C}$ for 30 s. The expression levels were analyzed using ABI 7500 software and the relative expression quantified using the comparative CT method with endogenous GAPDH levels. The primer sequences used for PCR amplification were as follows: HSP27 (F) 5'-ACCATTCCCGTCACCTTCC-3' and (R) 5' -TCTTTACTTGTTTCCGGCTGTT-3', HSP70 (F) 5' -CGTGATGACCGCCCTGAT-3' and (R) 5' -CGGCTGGTTGTCCGAGTA-3', HSP90 (F) 5' -TTCTATCTCGGGCTTGTC-3' and (R) 5'-CACCCTCAAGATTGTCAGC-3', and GAPDH, (F) 5'-CACCCTCAAGATTGTCAGC-3' and (R) 5' TAAGTCCCTCCACGATGC-3'.

\section{Statistical analysis}

All data collected and recorded were analyzed by oneway analysis of variance (ANOVA) and Duncan's multiple comparisons using the SPSS 17.0 software program (SPSS,

Table 2. Effects of short-term heat stress on body temperature and respiration rate of Hanwoo steer

\begin{tabular}{|c|c|c|c|}
\hline \multirow{2}{*}{ Item } & \multicolumn{3}{|c|}{ Treatments } \\
\hline & 0 day & 3 days & 6 days \\
\hline Flank, ${ }^{\circ} \mathrm{C}$ & $20.0^{b} \pm 0.58$ & $36.8^{a} \pm 0.63$ & $38.5^{\mathrm{a}} \pm 1.19$ \\
\hline Rump, ${ }^{\circ} \mathrm{C}$ & $20.0^{b} \pm 0.33$ & $37.0^{a} \pm 0.41$ & $38.5^{\mathrm{a}} \pm 1.19$ \\
\hline Perineum, ${ }^{\circ} \mathrm{C}$ & $30.0^{b} \pm 0.58$ & $37.3^{\mathrm{a}} \pm 0.48$ & $39.5^{\mathrm{a}} \pm 1.14$ \\
\hline Foot, ${ }^{\circ} \mathrm{C}$ & $18.0^{b} \pm 0.58$ & $37.5^{a} \pm 0.58$ & $39.0^{\mathrm{a}} \pm 1.41$ \\
\hline Rectal, ${ }^{\circ} \mathrm{C}$ & $38.6^{b} \pm 0.03$ & $38.9^{b} \pm 0.04$ & $40.5^{\mathrm{a}} \pm 0.89$ \\
\hline Respiration, breaths/min & $39.3^{b} \pm 0.65$ & $88.6^{a} \pm 0.96$ & $86.4^{a} \pm 0.63$ \\
\hline
\end{tabular}

Means with different letters differ significantly $(p<0.05)$.
Chicago, IL, USA). Experimental results were expressed as mean \pm SEM. A $p$-value $<0.05$ and was considered statistically significant.

\section{RESULTS}

\section{Physiological parameters}

The results as effects of heat stress on body temperature, rectal temperature and respiration rate are presented in Table 2. All the body temperature of each parts (frank, rump, perineum and foot) significantly elevated in both heat stress groups ( 3 days and 6 days) compared with the control group ( 0 day) $(p<0.05)$, with no significant difference between 3 days and 6 days. Rectal temperature slightly elevated in 3 days $\left(38.9 \pm 0.04^{\circ} \mathrm{C}\right)$, and in 6 days $\left(40.5 \pm 0.89^{\circ} \mathrm{C}\right)$ as well as in 0 day $\left(38.6 \pm 0.03^{\circ} \mathrm{C}\right)(p<$ $0.05)$. Moreover, respiration rates markedly increased in 3 days and 6 days $(88.6 \pm 0.96 \mathrm{bpm}$ and $86.4 \pm 0.63 \mathrm{bpm}$, respectively) than in 0 days $(39.3 \pm 0.65 \mathrm{bpm})(p<0.05)$. There were no temperature and respiration rate differences due to the different check time schedule in the morning and in the afternoon (data not shown). In addition, moderate panting, presence of drool, and standing were behaviors observed in heat stress groups (data not shown).

Effects of heat stress on feed intake are shown in Table 3. Feed intake decreased in both heat stress groups (3 days and 6 days, $3.7 \pm 0.14 \mathrm{~kg}$ and $4.0 \pm 0.15 \mathrm{~kg}$, respectively) compared with the control group (0 day, $5.0 \pm 0.00 \mathrm{~kg}$ ) $(p<0.05)$. Interestingly, concentrate feed intake slightly increased in 6 days $(2.6 \pm 0.16 \mathrm{~kg})$ than 3 days $(2.3 \pm$ $0.05 \mathrm{~kg}$ ) with no difference observed between treatment groups. But roughage intake has no difference between 3 days and 6 days.

Effects of heat stress on change of body weight (BW) are presented in Table 4. Heat stress resulted a significant decreased of final BW for both heat stress groups (3 days

Table 3. Effects of short-term heat stress on feed intake of Hanwoo steer

\begin{tabular}{lccc}
\hline \multirow{2}{*}{ Item } & \multicolumn{3}{c}{ Treatments } \\
\cline { 2 - 4 } & 0 day & 3 days & 6 days \\
\hline Concentrate & $3.0^{\mathrm{a}} \pm 0.0$ & $2.3^{\mathrm{b}} \pm 0.05$ & $2.6^{\mathrm{b}} \pm 0.16$ \\
Roughage & $2.0^{\mathrm{a}} \pm 0.0$ & $1.4^{\mathrm{b}} \pm 0.09$ & $1.4^{\mathrm{b}} \pm 0.06$ \\
Total & $5.0^{\mathrm{a}} \pm 0.0$ & $3.7^{\mathrm{b}} \pm 0.14$ & $4.0^{\mathrm{b}} \pm 0.15$ \\
\hline
\end{tabular}

Means with different letters differ significantly $(p<0.05)$. 
and 6 days, $211.8 \pm 4.75 \mathrm{~kg}$ and $215.5 \pm 3.50 \mathrm{~kg}$, respectively) compared with the control group (0 day, $240.0 \pm$ $25.00 \mathrm{~kg})(p<0.05)$. The BW gain was significantly lower in 3 days $(-35.8 \pm 2.25 \mathrm{~kg})$ and 6 days $(-31.0 \pm 2.00 \mathrm{~kg})$ than in 0 day $(5.5 \pm 0.50)(p<0.05)$. The BW gain was slightly lower in 3 days than in 6 days, however the difference was not significant between treatment groups.

The results of serum biochemistry analysis are shown in Fig. 1. These results showed that heat stress did not

Table 4. Effects of short-term heat stress on BW of Hanwoo steer

\begin{tabular}{cccr}
\hline \multirow{2}{*}{ Items } & \multicolumn{3}{c}{ Treatments } \\
\cline { 2 - 4 } & 0 day & 3 days & 6 days \\
\hline Initial BW, $\mathrm{kg}$ & $234.5 \pm 24.5$ & $247.5 \pm 7.00$ & $246.5 \pm 5.50$ \\
Final BW, kg & $240.0^{\mathrm{a}} \pm 25.00$ & $211.8^{\mathrm{b}} \pm 4.75$ & $215.5^{\mathrm{b}} \pm 3.50$ \\
BW gain, kg & $5.5^{\mathrm{b}} \pm 0.50$ & $-35.8^{\mathrm{a}} \pm 2.25$ & $-31.0^{\mathrm{a}} \pm 2.00$ \\
\hline
\end{tabular}

Means with different letters differ significantly $(p<0.05)$. affect the blood parameters. The serum glucose, cholesterol, and albumin concentration were slightly lower in both heat stress groups ( 3 days and 6 days) compared with the control group ( 0 day). Whereas, the serum creatinine and alanine aminotransferase (ALT) concentration were slightly higher in both heat stress groups ( 3 days and 6 days) than the control group (0 day). Meanwhile, BUN concentration was slightly lower in 3 days, but higher in 6 days than in 0 day. All blood parameters observed has no significant correlation in control group as well as heat stress groups. Moreover, all blood parameters were within the reference range (reference range not shown).

\section{Serum T3 and cortisol concentrations}

Effects of heat stress on serum T3 and cortisol concentrations are presented in Fig. 2. Results showed that heat stress increased serum T3 concentration in both heat stress groups ( 3 days and 6 days, $4.10 \mathrm{ng} / \mathrm{mL}$ and 3.79
A
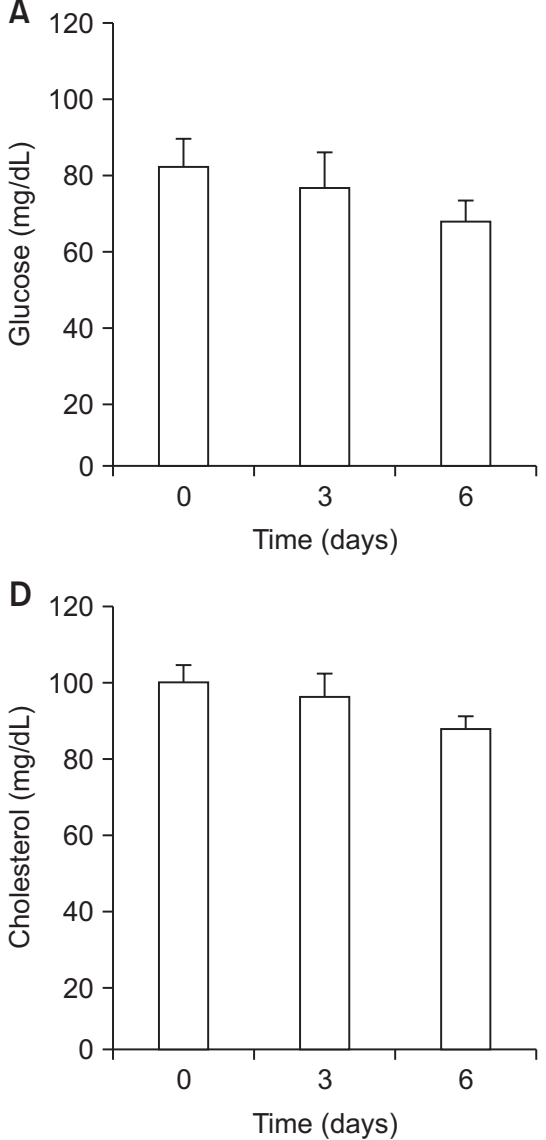

B 20

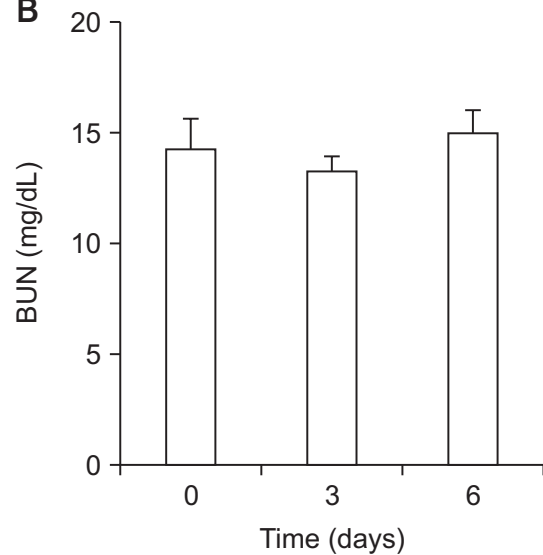

$\mathrm{E}$

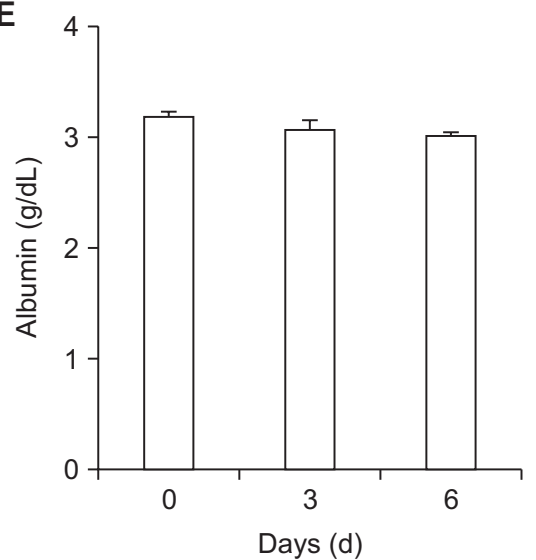

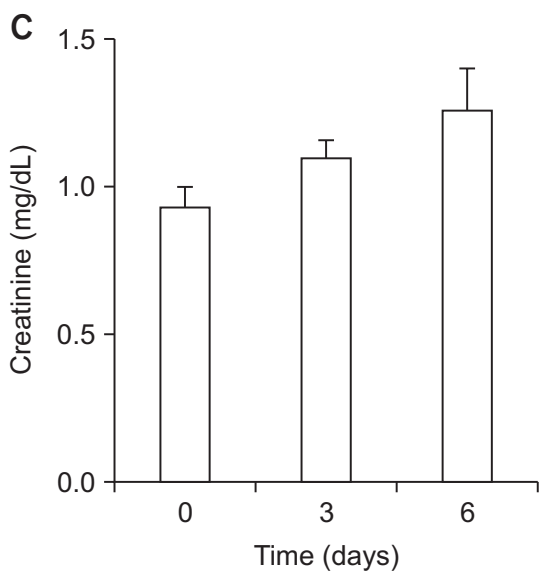

$\mathrm{F}$

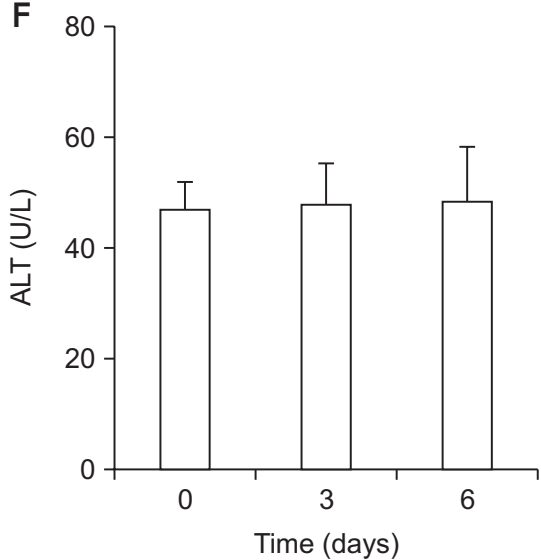

Fig. 1. Effects of short-term heat stress on blood parameter (A to D) of Hanwoo steer by IDEXX Dx Chemistry Analyzer. Measured concentration of (A) glucose, (B) blood urea nitrogen (BUN), (C) creatinine, (D) cholesterol, (E) albumin and (F) alanine aminotransferase (ALT) from serum collected in control group ( 0 day) and heat stress groups ( 3 and 6 days). 

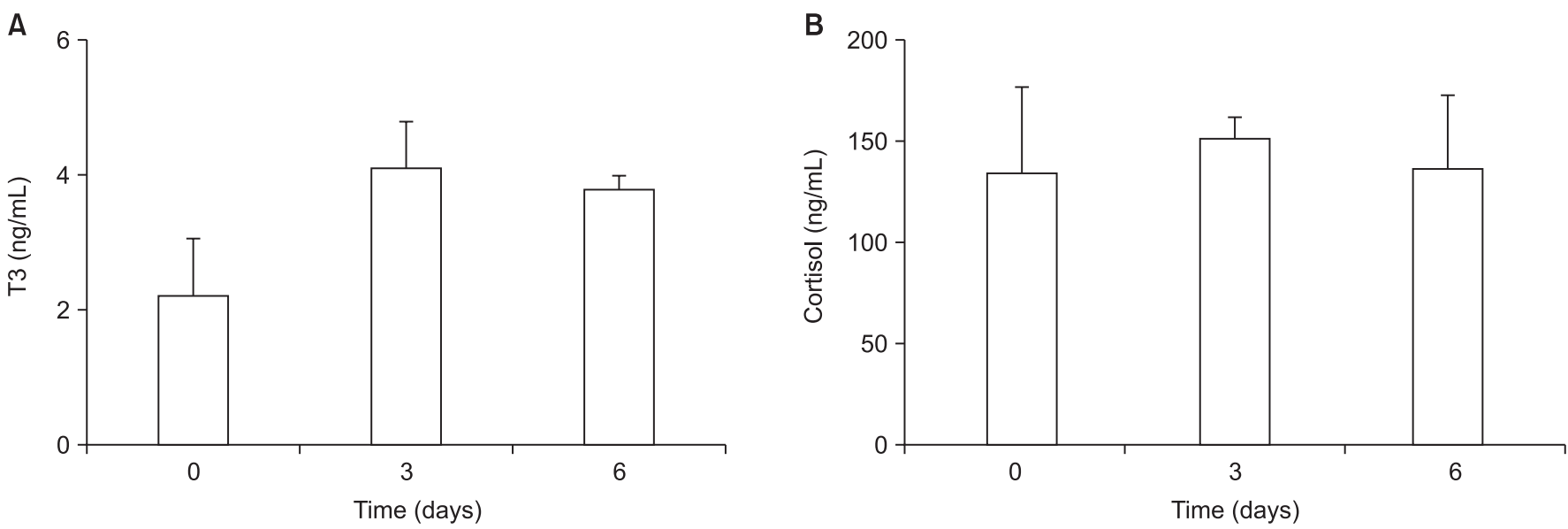

Fig. 2. Effects of short-term heat stress on serum triiodothyronine (T3) and cortisol of Hanwoo steer by ELISA. Measured concentration of (A) T3 and (B) cortisol from serum collected in control group ( 0 day) and heat stress groups (3 and 6 days).
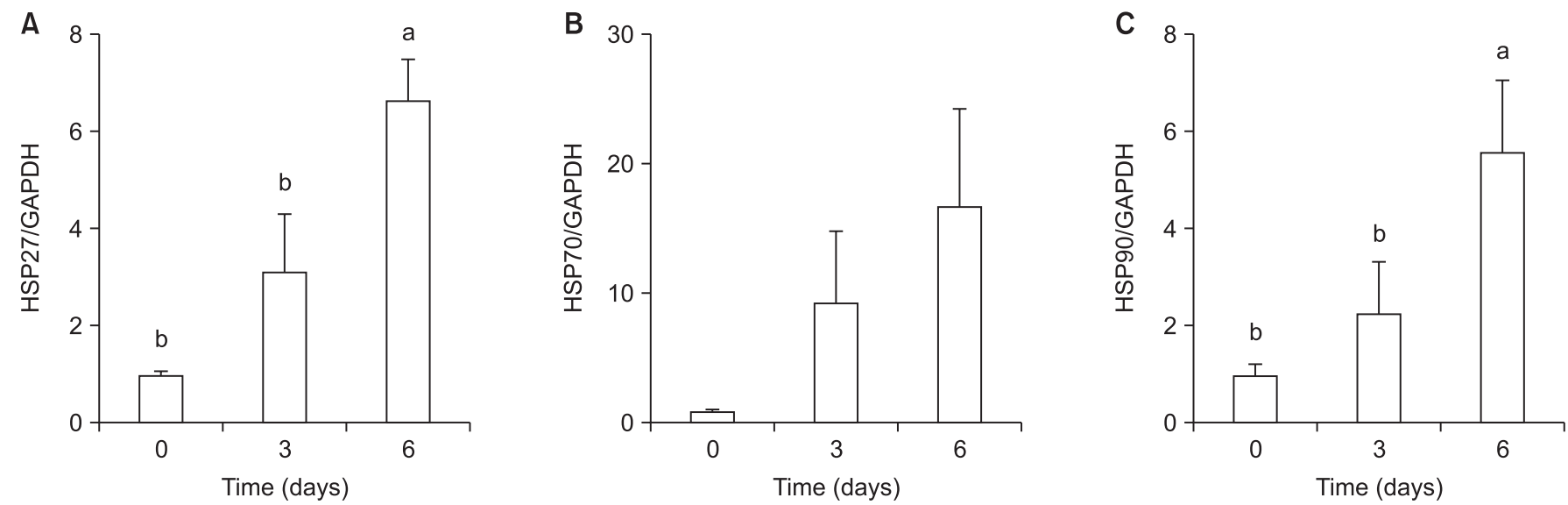

Fig. 3. Effects of short-term heat stress on liver HSP27, HSP70 and HSP90 (A to C) gene expression of Hanwoo steer. Total RNA was isolated from liver tissue in control group ( 0 day) and heat stress groups ( 3 and 6 days) and real-time PCR was performed with specific primers for (A) HSP27, (B) HSP70 and (C) HSP90. Means with different letters differ significantly $(p<0.05)$.

$\mathrm{ng} / \mathrm{mL}$, respectively) compared with the control group (0 days, $2.24 \mathrm{ng} / \mathrm{mL})$. Moreover, serum cortisol concentration increased in both heat stress groups ( 3 days and 6 days, $151.4 \mathrm{ng} / \mathrm{mL}$ and $137.4 \mathrm{ng} / \mathrm{mL}$, respectively) than in 0 days control group (134.4 ng/mL), but there was no significant difference could be observed. Interestingly, both T3 and cortisol concentration increased in 3 days and then slightly declined in 6 days.

\section{Liver tissue HSPs (27, 70 and 90) gene expression}

Effects of heat stress on HSP27, HSP70 and HSP90 gene expression in liver tissue are shown in Fig. 3. Results found that level of HSP27, HSP70, and HSP90 mRNA expression were upregulated by heat stress. HSP27 mRNA expression level increased in 3 day ( 3.1 fold), and signifi- cantly increased in 6 days ( 6.6 fold) than in 0 day ( 1 fold) $(p<0.05)$. In addition, HSP90 mRNA expression level increased in 3 days (2.3 fold), and in 6 days ( 5.6 fold) and significantly increased compared with that in 0 day (1 fold) $(p<0.05)$. Meanwhile, HSP70 mRNA expression level was found to be higher in both heat stress groups (3 days and 6 days, 9.2 fold and 16.7 fold, respectively) compared with the control group ( 0 day, 1 fold) with no significant difference.

\section{Serum HPSs concentrations}

Effects of heat stress on serum heat shock proteins concentrations are presented in Fig. 4. As expected, serum concentration of HSP27, HSP70, and HSP90 increased during heat stress condition. Serum HSP27 concentration 

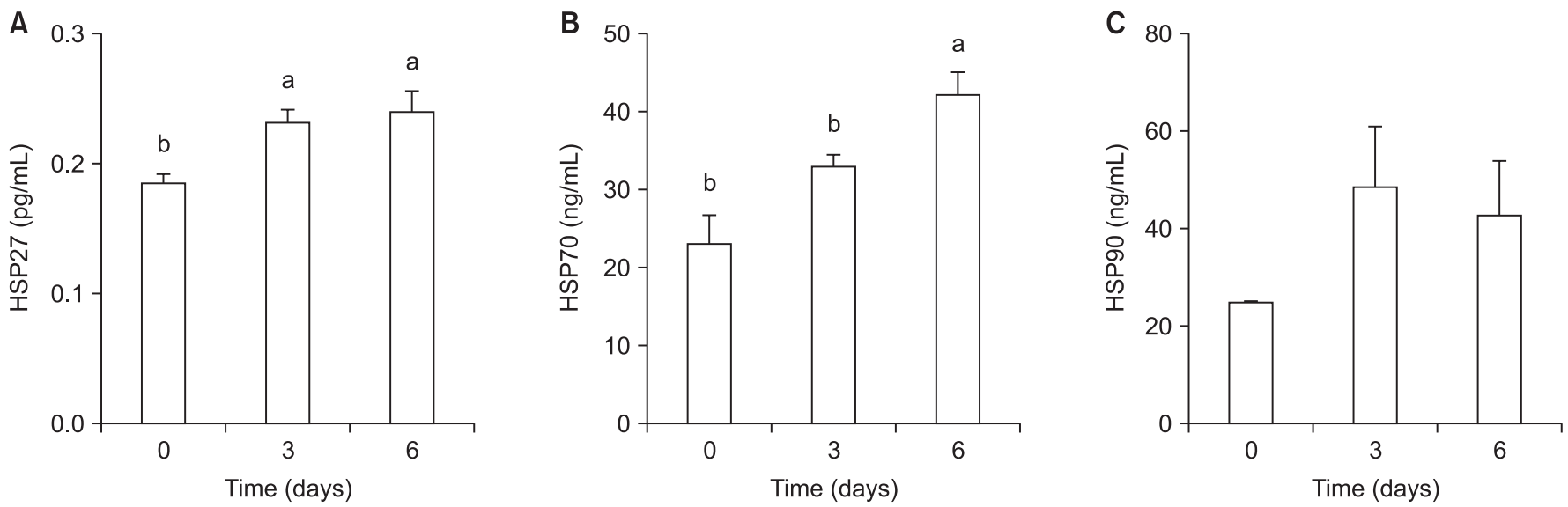

Fig. 4. Effects of short-term heat stress on serum HSP27, HSP70 and HSP90 (A to C) of Hanwoo steer by ELISA. Measured concentration of (A) HSP27, (B) HSP70 and (C) HSP90 from serum collected in control group (0 day) and heat stress groups (3 and 6 days). Means with different letters differ significantly $(p<0.05)$.

significantly increased in both heat stress groups ( 3 days and 6 days, $0.23 \pm 0.01 \mathrm{pg} / \mathrm{mL}$ and $0.24 \pm 0.02 \mathrm{pg} / \mathrm{mL}$, respectively) compared with the control group (0 days, $0.18 \pm 0.01 \mathrm{pg} / \mathrm{mL})(p<0.05)$. In addition, serum HSP70 concentration increased in 3 days $(32.9 \pm 4.09 \mathrm{ng} / \mathrm{mL})$, and significantly increased in 6 days $(42.5 \pm 2.54 \mathrm{ng} / \mathrm{mL})$ than in 0 day $(23.4 \pm 3.66 \mathrm{ng} / \mathrm{mL})(p<0.05)$. On the other hand, serum HSP 90 concentration increased in both heat stress groups $(3$ days and 6 days, $44.0 \pm 9.95 \mathrm{ng} / \mathrm{mL}$ and $42.8 \pm 11.28 \mathrm{ng} / \mathrm{mL}$, respectively) than with the control group $(27.7 \pm 1.72 \mathrm{ng} / \mathrm{mL})$, but there was no significant difference observed.

\section{DISCUSSION}

Global warming is predicted to cause a lot of damage to the livestock industry in the world (St-Pierre et al., 2003). These heat stress effects on cattle have already been studied extensively (West, 2003). Recently, many reports suggested that South Korea is no longer a safe area from global warming (Boo et al., 2004; Park and Suh, 2011). Despite the establishment of environmental management and cooling system, heat stress is expected to greatly affect Hanwoo cattle industry in South Korea, in the near future. However, only few have studied Hanwoo cattle under heat stress. Therefore, this study was conducted to evaluate the effect of short-term acute heat stress on physiological response, blood parameter, level of serum T3 and cortisol, and HSPs of Hanwoo cattle.

Body temperature and respiration rate are closely relat- ed to heat stress. These present results showed that heat stress clearly caused remarkable increase of temperature on body and rectal, and more than twofold increase in respiration rate (Table 2). These results are generally in agreement with the study conducted by West (2003) that heat stress occurs in the ambient temperature, solar radiation, and humidity and is higher than the surface temperature of skin and heat load on animal body. Accordingly, increased body temperature and respiration rate are well-known phenomena of heat stress, which physiological change enhanced heat dissipation and reduced heat production (Moseley, 1998). Furthermore, physiological changes such as increasing peripheral blood flow, panting, increase energy expenditures, and reduced activity will reduce heat production (NRC, 2001).

Feed and roughages intake significantly decreased in heat stress groups, compared with control group (Table 3 ). One of the most noticeable consequences of heat stress is reduced dry matter intake (DMI). Reduced feed intake caused by heat stress was traditionally assumed to be primary response, and it is a way to decrease heat production in warm environment because the feed metabolism increases the heat of the ruminant (West, 2003). Furthermore, heat stress has a direct negative effect on appetite as dictated by hypothalamus to decrease feed intake, which results in a net decrease in nutrient energy availability for production (Collier et al., 1982). In addition, heat stress reduces the digestibility of roughage and increases gut-fill by change rumen microbial population and pH (Das et al., 2016). Consequently, heat stress result- 
ed in significant decrease on BW (Table 4) which is similar to the results of other studies (O'Brien et al., 2010). These results found that heat stress clearly caused noticeable reduce feed intake and BW loss.

Blood parameters analysis can give information about their physiological state. For blood parameters analysis was observed with no specific pattern between control group and heat stress groups (Fig. 1). Levels of serum glucose, cholesterol, and albumin were slightly decreased by heat stress, caused by consistent negative energy balance (Rassooli et al., 2004). Ronchi et al. (1999) reported that heat stressed cattle have reduced albumin secretion and liver enzyme. Whereas, our results showed that BUN, creatinine, and ALT slightly increased by heat stress, however, there was no difference observed in groups. In addition, all groups were within normal reference range. Similar results were also reported by Nazifi et al. (2003) about an Iranian sheep during thermal stress $\left(40^{\circ} \mathrm{C}\right)$. As a results implicated that short-term acute heat stress do not significantly affect any immune responses and liver function of Hanwoo cattle.

The endocrinal level, thyroid and adrenal hormones secretions are important in animal adaptation mechanism to thermal stress (Sharma et al., 2013). The serum concentration of T3 and cortisol had no significant differences between control group and heat stress groups (Fig. 2). Results showed that heat stress slightly increased serum concentration of T3 in 3 days, and then slightly dropped in 6 days. Kahl et al. (2015) reported that increased ambient temperature reduced circulating concentration of thyroid hormones. Similar results have been reported that serum T3 and T4 were lower in summer than in winter (Rasooli et al., 2004). While a reduced thyroid activity in thermal acclimated cattle has been reported by Gale (1973). As a general observation, lower feed intake together with a decrease circulating endogenous levels of thyroid hormones is an adaptive mechanism under heat stress (Collier et al., 1982).

As a result, heat stress slightly increased serum concentration of cortisol in 3 days, and then dropped in 6 days (Fig. 2). These results are in agreement with the reports of Wise et al. (1988), who found that heat stress could cause increased serum cortisol concentration. Whereas prolonged heat is accompanied by slight declines in plasma concentration of cortisol (Ingraham et al., 1979). Unexpectedly, the results of this study have some difference from general trends, which might be due to the volume of water intake and limited number of experimental animals. Meanwhile, Hansen. (2004) reported that during genetic adaptation, Zebu cattle have acquired thermotolerant genes, and therefore have a higher degree of thermotolerance compared with Bos taurus species. Han (1996) suggested that Hanwoo cattle could be a cross between Zebu and Taurine cattles. Otherwise, there might be other adaptive responses of Hanwoo cattle under heat stress. Thus, further research is necessary.

HSPs expression has been reported by $S \varnothing$ rensen et al. (2003), that there is universal cellular stress response in all organs (e.g., liver and muscle). Furthermore, HSPs expressions are considered as potential indicators of animal adaptation to harsh environmental stress (Hansen, 2004). The liver is the main metabolic organ coordinating the adaptations of animal. Thus, the HSPs expression in liver tissue was evaluated and then serum concentration was measured. Heat stress increased HSP27, HSP70, and HSP90 mRNA expression in liver tissue (Fig. 3). Similarly, Kristensen and Løvendahl (2006) found that muscle HSP72 concentration increased significantly upon exposure to heat. Using in vitro, elevated incubation temperatures induce HSP70 mRNA expression in bovine mammary epithelial cells (Collier et al., 2008). As expected, the same tendencies were confirmed with serum concentration of HSP27, HSP70, and HSP90 (Fig. 4). Similarly, Min et al. (2015) reported that heat stress significantly increased serum concentration of HSF, HSP27, HSP70, and HSP90 in dairy cow. In cattle, thermal stress conditions increased HSP72 concentration in plasma and HSP70 gene expression in Holstein skin (Roy and Collier, 2012). Therefore, these results suggested that heat stress induced activation of the HSPs response in cells, which could lead to secretion of HSPs into the extracellular and blood in Hanwoo cattle. However, Kristensen and Løvendahl (2006) reported that there might be little correlation between HSPs concentration in muscle tissue and plasma for cattle exposed to heat stress. Thus, further research also needed.

\section{CONCLUSION}

In this study demonstrated that heat stress affect the induced body, rectal temperature and respiration rate with reduced feed intake and body weight. In contrast, 
heat stress did not affect the blood parameter, secretion of T3 and cortisol. Nevertheless, heat stress significantly increased serum and liver tissue HSPs. We are concluded that it could be assumed that Hanwoo cattle may has high adaptation ability under heat stress condition due to the increase of heat stress resistance by the induction of the HSPs signal. Thus, we are recommended that parameters in this study like body temperature, respiration rate as well as serum and tissue HSPs could be appropriate indicators of Hanwoo cattle response to heat stress. However, future studies will need to have more number of animals, varied age, variety tissue, sex, lactation etc.

\section{CONFLICTS OF INTEREST}

No potential conflict of interest relevant to this article was reported.

\section{ACKNOWLEDGEMENTS}

This study was supported by 2016 Postdoctoral Fellowship Program of National Institute of Animal Science, Rural Development Administration, Republic of Korea. And, this work was carried out with the support of "Cooperative Research Program for Agriculture Science \& Technology Development (Project title: A study to improve the productivity and adaptability of Hanwoo to counter global warming, Project No. PJ010974012016)" Rural Development Administration, Republic of Korea.

\section{ORCID}

Youl-Chang Baek: https://orcid.org/0000-0003-4454-5339 Minseok Kim: https://orcid.org/0000-0002-8802-5661 Jin-Young Jeong: https://orcid.org/0000-0002-8670-7036 Young-Kyoon Oh: https://orcid.org/0000-0002-5817-1748 Sung-Dae Lee: https://orcid.org/0000-0002-9167-4099 Yoo-Kyung Lee: https://orcid.org/0000-0002-9896-4152 Sang-Yun Ji: https://orcid.org/0000-0001-7235-3655 Hyuck Choi: https://orcid.org/0000-0002-7047-6472

\section{REFERENCES}

Boo KO, Kwon WT, Oh JH, Baek HJ. 2004. Response of global warming on regional climate change over Korea: An experiment with the MM5 model. Geophys Res Lett. 31:L21206.
Collier RJ, Collier JL, Rhoads RP, Baumgard LH. 2008. Invited review: Genes involved in the bovine heat stress response. J Dairy Sci. 91:445-454.

Collier RJ, Doelger SG, Head HH, Thatcher WW, Wilcox CJ. 1982. Effects of heat-stress during pregnancy on maternal hormone concentrations, calf birth-weight and postpartum milk-yield of holstein cows. J Anim Sci. 54:309-319.

Das R, Sailo L, Verma N, Bharti P, Saikia J, Imtiwati, Kumar R. 2016. Impact of heat stress on health and performance of dairy animals: A review. Vet World. 9:260-268.

Gale CC. 1973. Neuroendocrine aspects of thermoregulation. Annu Rev Physiol. 35:391-430.

Han SW. 1996. The breed of cattles. Sun-Jin publishing, pp. 14860.

Hansen PJ. 2004. Physiological and cellular adaptations of zebu cattle to thermal stress. Anim Reprod Sci. 82:349-360.

Houghton JT, Ding Y, Griggs DJ, Noguer M, van der Linden PJ, Dai X, Maskell K, Johnson CA. 2001. Climate change 2001: The science of climate change, the third assessment report of the intergovernmental panel on climate change. Cambridge Univ press. New York.

Ingraham RH, Stanley RW, Wagner WC. 1979. Seasonal effects of tropical climate on shaded and non-shaded cows as measured by rectal temperature, adrenal-cortex hormones, thyroid-hormone, and milk-production. Am J Vet Res. 40:17921797.

Kahl S, Elsasser TH, Rhoads RP, Collier RJ, Baumgard LH. 2015. Environmental heat stress modulates thyroid status and its response to repeated endotoxin challenge in steers. Domest Anim Endocrin. 52:43-50.

Kristensen TN, Løvendahl P. 2006. Physiological responses to heat stress and their potential use as indicators of reduced animal welfare in jersey calves. Acta Zool Sinica. 52:681-689.

Melesse A, Maak S, Schmidt R, Von Lengerken G. 2011. Effect of long-term heat stress on key enzyme activities and T3 levels in commercial layer hens. Int J Livest Prod. 2:107-116.

Min L, Cheng JB, Shi BL, Yang HJ, Zheng N, Wang JQ. 2015. Effects of heat stress on serum insulin, adipokines, AMPactivated protein kinase, and heat shock signal molecules in dairy cows. J Zhejiang Univ Sci B. 16:541-548.

Mitchell JFB. 1989. The greenhouse-effect and climate change. Rev Geophys. 27:115-139.

Moseley PL. 1998. Heat shock proteins and the inflammatory response. Ann N Y Acad Sci. 856:206-213.

National Research Council. 2001. Nutrient requirements of dairy cattle. 7th rev. ed. National Academy Press. Washington, DC.

Nazifi S, Saeb M, Rowghani E, Kaveh K. 2003. The influences of thermal stress on serum biochemical parameters of Iranian fat-tailed sheep and their correlation with triiodothyronine (T3), thyroxine (T4) and cortisol concentrations. Comp Clin Path. 12:135-139.

O'Brien MD, Rhoads RP, Sanders SR, Duff GC, Baumgard LH. 2010. Metabolic adaptations to heat stress in growing cattle. Domest Anim Endocrin. 38:86-94. 
Park WS, Suh MS. 2011. Characteristics and trends of tropical night occurrence in South Korea for recent 50 years (19582007). Atmosphere. 21:361-371.

Pereira AMF, Baccari F, Titto EAL, Almeida JAA. 2008. Effect of thermal stress on physiological parameters, feed intake and plasma thyroid hormones concentration in Alentejana, Mertolenga, Frisian and Limousine cattle breeds. Int J Biometeorol. 52:199-208.

Rasooli A, Nouri M, Khadjeh GH, Rasekh A. 2004. The influences of seasonal variations on thyroid activity and some biochemical parameters of cattle. Iran J Vet Res. 5:1383-1391.

Ronchi B, Bernabucci U, Lacetera N, Verini Supplizi A, Nardone A. 1999. Distinct and common effects of heat stress and restricted feeding on metabolic status in holstein heifers. Zoot Nutr Anim. 25:71-80.

Roy KS, Collier RJ. 2012. Regulation of acclimation to environmental stress. Environmental physiology of livestock. 1st ed. Collier RJ (Ed.), John Wiley \& Sons, Chichester UK, pp. 4954.

Sharma S, Ramesh K, Hyder I, Uniyal S, Yadav VP, Panda RP, Maurya VP, Singh G, Kumar P, Mitra A, Sarkar M. 2013. Effect of melatonin administration on thyroid hormones, cortisol and expression profile of heat shock proteins in goats (Capra hircus) exposed to heat stress. Small Rumin Res. 112:216223.

Silanikove N. 2000. Effects of heat stress on the welfare of extensively managed domestic ruminants. Livest Prod Sci. 67:118.

St-Pierre NR, Cobanov B, Schnitkey G. 2003. Economic losses from Heat Stress by US livestock industries. J Dairy Sci. 86:52-77.

Stringer LC, Dyer JC, Reed MS, Dougill AJ, Twyman C, Mkwamnisi D. 2009. Adaptations to climate change, drought and desertification: local insights to enhance policy in southern Africa. Environ Sci Policy. 12:748-765.

Sørensen JG, Kristensen TN, Loeschcke V. 2003. The evolutionary and ecological role of heat shock proteins. Ecol Lett. 6:1025-1037.

West JW. 2003. Effects of heat-stress on production in dairy cattle. J Dairy Sci. 86:2131-2144.

Wise ME, Armstrong DV, Huber JT, Hunter R, Wiersma F. 1988. Hormonal alterations in the lactating dairy cow in response to thermal stress. J Dairy Sci. 71:2480-2485. 